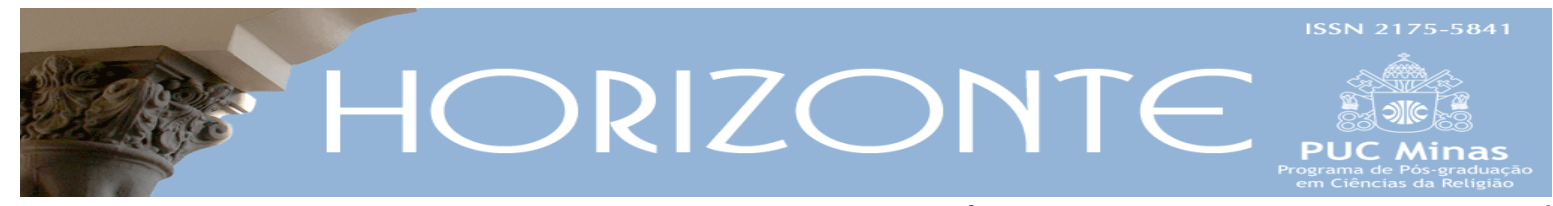

Temática Livre - Artigo original

DOI - 10.5752/P.2175-5841.2014v12n36p1334

\title{
A filosofia da religião e seu objeto em Paul Tillich e Jean-Luc Marion
}

Philosophy of Religion and its subject in Paul Tillich and Jean-Luc Marion

Frederico Pieper Pires *

\begin{abstract}
Resumo
O tema da filosofia da religião é a religião. Essa frase parece ser óbvia. No entanto, ela perde sua obviedade quando perguntamos como devemos compreender a religião. Mais diretamente: como se pode manter a vocação crítica do questionamento filosófico e, ao mesmo tempo, ouvir a religião no que ela tem de específico? A filosofia da religião encontra-se num impasse: ou deixa escapar seu objeto por meio da redução à subjetividade, ou caso ouça seu objeto atentamente deve negar suas pretensões de conhecimento, reconhecendo-se como tarefa irrealizável. Apesar de pertencerem a tradições filosóficas distintas, essa pergunta é feita por Paul Tillich e pelo fenomenólogo francês Jean-Luc Marion. $\mathrm{O}$ artigo explora como ambos os autores partem de problemática similar (buscando uma compreensão nãoreducionista de religião), seguem por caminhos distintos (enquanto Tillich busca uma síntese entre filosofia e religião, Marion insiste na distinção), mas, no final, ambos apelam para a teologia a fim de sustentar a especificidade da religião.
\end{abstract}

Palavras-chave: religião; filosofia; fenomenologia; Tillich; Marion.

\begin{abstract}
The subject of the philosophy of religion is religion. This sentence seems to be obvious. However, it loses its obviousness when we ask how we must comprehend religion. More directly: how can one maintain the critical vocation of philosophical inquires and, at the same time, listen to religion in what it has of specific? Philosophy of religion is deadlocked: or misses its object by reducing it to the subjectivity, or if it pays close attention to its subject, it should deny its claims to knowledge, recognizing itself as an impossible task. Although they belong to different philosophical traditions, this question is put is posed by Paul Tillich and by French phenomenologist Jean-Luc Marion. The article explores how both authors have the similar problematic (seeking a non-reductionist understanding of religion), follow different paths (while Tillich seeks a synthesis between philosophy and religion, Marion insists on the distinction) but, at the end, they appeal to theology in order to sustain the specificity of religion.
\end{abstract}

Keywords: Religion; philosophy; phenomenology; Tillich; Marion.

Artigo recebido em 15 de Junho de 2014 e aprovado em 17 de Novembro de 2014.

* Doutor em Filosofia. Professor na Universidade Federal de Juiz de Fora. País de origem: Brasil. E-mail: fredericopieper@gmail.com.

Horizonte, Belo Horizonte, v. 12, n. 36, p. 1334-1368, out./dez. 2014 - ISSN 2175-5841 


\section{Introdução}

O tema da filosofia da religião é a religião. Nada soa como mais óbvio. Assim como a filosofia da arte estuda a arte, ou a filosofia política aborda questões concernentes às organizações políticas humanas, nada mais natural do que essa afirmação: o objeto da filosofia da religião é a religião. Nessa perspectiva, o da de filosofia $d a$ religião é compreendido como genitivo objetivo. Não se propõe, portanto, desenvolver uma filosofia a partir da religião (como se fosse pertencente à religião), mas trata-se de um âmbito do pensar filosófico que se ocupa com importante dimensão humana: a religião. Portanto, dizer que o tema da filosofia da religião é a religião parece ser nada mais do que um pleonasmo, mera redundância que apenas explicita aquilo que já estava pressuposto no nome mesmo da disciplina.

No entanto, na obviedade dessa afirmação se escondem problemas de ordem epistemológica que marcam especificamente a relação entre a filosofia da religião e seu "objeto". Em que termos essa articulação entre um âmbito do saber filosófico e seu objeto se constitui como problemática? O objeto da filosofia da religião não se deixa apreender plenamente, resistindo à mera classificação de objeto. Essa problemática é tratada tanto por Paul Tillich, ainda na década de $1920^{1}$, como por Marion, em textos mais recentes. Não obstante a diferença temporal e de tradição filosófica entre os autores, problema similar se interpõe: como tratar filosoficamente o tema da religião? Nesse ensaio, tem-se por objetivo mostrar como ambos, um a partir de um background mais idealista e outro fenomenológico, colocam problema similar, buscando encaminhamentos distintos. Enquanto Tillich persegue a síntese entre religião e filosofia, Marion segue na direção de, ao menos incialmente, indicar uma distinção, colocando em relevo a particularidade e autonomia de cada disciplina. Não obstante seguirem por sendas distintas, ambos chegam a lugar similar. Ao final, parece que a filosofia da religião, a fim de tratar de

\footnotetext{
${ }^{1}$ No caso de Tillich, este artigo se utiliza dos seguintes textos: A superação do conceito de religião na filosofia da religião (1922); O sistema das ciências (1923) e Filosofia da religião (1925).
} 
modo adequado seu objeto, deve recorrer (quando não sobreposta) à teologia. Analisemos essas questões mais de perto.

\section{0 problema}

Como observado, o problema fundamental da filosofia da religião é que seu tema resiste em ser considerado como mero “objeto”. Mas em que aspectos se dá essa resistência por parte da religião?

No texto A superação do conceito de religião na filosofia da religião (1922), Tillich menciona quatro reduções às quais o conceito de religião submete a religião: 1)Ele faz com que a certeza de Deus fique na dependência do ego; 2)Ele conduz à compreensão de Deus como relativo ao mundo; 3) Ele leva à abordagem da religião como relativa à cultura, como uma função do espírito humano ao lado de outras; 4) Por fim, no conceito de religião, a revelação é relativa à história da religião. Vejamos, com pouco mais de detalhes cada aspecto apontado por Tillich.

1) No conceito de religião, a certeza do incondicional (nesse caso, Tillich emprega o termo Deus) é dependente da certeza do ego. Em outros termos, o incondicional é relegado a um segundo plano, sendo que a certeza desse incondicional é condicionada pela certeza que o sujeito tem de si mesmo. Isso se deve ao fato de que o eu se coloca de modo mais próximo e presente a si mesmo, não se reconhecendo a necessidade do incondicional como meio de acesso a si mesmo. A interioridade da subjetividade não reconhece a anterioridade do incondicional. Assim, no conceito de religião, a certeza do eu é base para que se alcance a certeza de Deus. Mas, "Há dois elementos contidos na auto-certeza do eu: o incondicional de uma apreensão da realidade que se situa além do sujeito e do objeto, e a participação do eu subjetivo nessa efetividade incondicionada que a sustenta" (TILLICH, 1987, p.81). Opondo-se ao conceito de religião, a religião concebe o eu como meio; não é aquilo que suporta, mas o eu se mostra como o que é suportado. Cabe ressaltar que o incondicional não é nenhum tipo de objeto. Antes, é espécie de horizonte que se coloca antes do sujeito e do objeto, 
fundamento sobre o qual se assentam todos os juízos teóricos. Em termos mais filosóficos, o incondicional é a condição de possibilidade para o sujeito e objeto, bem como para o encontro entre eles. Em suma, no conceito de religião o incondicional é considerado a partir daquilo que é condicionado: o sujeito. Aqui está a primeira redução, afinal na religião, o incondicional se mostra como anterior e fundamento do eu.

2) Uma vez que no conceito de religião se desloca a certeza do incondicional para o eu, ele perde também sua realidade, de modo que a religião passa a ser considerada como mera função do condicionado. Como consequência, há afirmação de um Deus abaixo de Deus (como se observa no deísmo, por exemplo) ou então há a identificação de Deus com o mundo. Se Deus é igualado ao mundo, já não pode ser tido como o incondicional. O essencial nesses dois casos é que a religião deixa de lidar com o que é incondicional, para, enquanto mera função entre outras, restringir-se à realidade do que é condicionado, sendo apreendido como aquilo que é correlato ao mundo. No entanto, para a religião, “o verdadeiro incondicional está além tanto deste Deus como do mundo” (TILLICH, 1987, p.75). No conceito de religião, a religião perde sua característica peculiar de relação com o incondicional, para se tornar uma esfera social ao lado ou entre outras. No entanto, a religião não aceita essa redução. Em suma, no conceito de religião, a religião destrói a si mesma.

3) Ao ser reduzida à subjetividade, como artefato cultural, a religião é interpretada como uma função do espírito humano entre outras. Assim, como o ser humano teria uma faculdade moral, estética ou de valores, ele possui uma faculdade religiosa. Desse modo, ao se restringir a religião ao sentimento (Gefühl Scheleiermacher) ou a um a priori (Troeltsch e Otto) ou mesmo como categoria mais elevada de ação, “O incondicional é colocado ao lado condicionado" (TILLICH, 1987, p. 75) ${ }^{2}$. Nessa perspectiva assim como uma pessoa pode agir do ponto de vista ético, social, econômico etc. age também do ponto de vista religioso.

\footnotetext{
2 Para Tillich, a religião não pode ser reduzida à esfera teórica (Hegel), nem à esfera prática (Kant), nem ao sentimento (Schleiermacher). "Religião não é sentimento; é uma atitude do espírito no qual elementos práticos, teóricos e emocionais estão unidos num todo complexo" (TILLICH, 1990, p. 72)
} 
Novamente, o incondicional é perdido, e a religião é transformada em mera esfera de ação social ao lado de outras. É apenas mais uma função do espírito humano, mera produção humana, estando submetida aos limites impostos pela subjetividade e, portanto, perde sua ligação com o incondicional.

4) Uma vez que o incondicional é dissolvido nas diversas funções do espírito humano, o caráter de singularidade e de absolutidade de determinada revelação é relativizada por meio de sua inserção numa abordagem histórica, como se fosse parte de um longo processo de desenvolvimento do ser humano, segundo os moldes da história da cultura e da religião. Do ponto de vista mais interno à religião, sua singularidade pode ser entendida no seu recurso à revelação. As diversas manifestações religiosas se pautam numa revelação. Determinada revelação, apesar de ser concernente a todos, é dada a uma pessoa ou a um grupo específico, possuindo caráter exclusivo e singular. Por outro lado, a filosofia lida com categorias generalizantes, que buscam apreender seu objeto destituindo-o de seus contornos particulares, para encontrar nele e por meio dele estruturas mais gerais e recorrentes. Nesse sentido, quando se denomina determinada religião (com sua revelação) de "religião", ela é privada de seu caráter absoluto, autosuficiente e singular. Ela se torna acontecimento relativo, já não possuindo mais o traço de ser uma ação da divindade, que se manifesta a determinado grupo, mas é tida como mero produto da cultura. É resultado da criatividade humana, sendo destituída de seu caráter transcendente. Nesse ponto, diante do intento generalizador da filosofia e o aspecto singular que a religião atribui a si mesma, instaura-se o conflito. A "revelação” aponta para o aspecto divino, único, absoluto, singular, exclusivo e auto-suficiente da "religião". O conceito de religião, por sua vez, a concebe como mero resultado das ações humanas, subordinando-se às criações culturais, sendo constituída de fatos relativos, recorrentes e nãoexclusivos.

Esses quatro âmbitos, nos quais se coloca o problema da relação entre o conceito de religião e a religião em Tillich, possuem características comuns. Em primeiro lugar, em todos eles a religião perde seu caráter incondicional. Traduzindo isso nos termos do problema acima proposto, é como se o conceito de 
religião a fim de objetivar seu tema tem de promover certa redução. Nesse movimento, a religião perde seu caráter peculiar e absoluto, para ser tratada sempre em relação a outro âmbito: a subjetividade do ego, o mundo, a cultura ou a história. Como se notará, Tillich não nega essas relações. Mas, isso não significa admitir que a religião deva ser colocada ao lado, em oposição ou subordinada a outra esfera da cultura, tal como se observa a partir do iluminismo. Essas características mais relativas da "religião" se devem justamente ao fato de ser tratada como dependente da subjetividade livre e criadora. Se forem produtos de uma subjetividade, as ações religiosas somente podem ser relativas em relação àquilo que é sua causa: o ser humano. Por outro lado, se a religião se entende como fundada numa revelação, ela se vê a si mesma como exclusiva e absoluta.

Em segundo lugar, cabe ressaltar que esses quatro elementos aqui apresentados são característicos da modernidade. Do ponto de vista histórico, é nesse período que a religião perde seu lugar de absolutidade para se tornar uma esfera entre outras. A superação dessa fragmentação da modernidade em esferas sociais autônomas com seus processos de legitimação próprios, no bojo do qual acaba restando à religião ser uma dessas esferas sociais entre outras. Nesse sentido, vale lembrar a afirmação de W. Smith: "Em todo caso, não é totalmente estulto sugerir que o surgimento do conceito 'religião' está de alguma forma correlacionado com um declínio na prática da religião em si” (SMITH, 2006, p.30). Assim, o uso mais recorrente do conceito de religião aparece justamente no período em que Ocidente assiste ao enfraquecimento da religião. Dito de outro modo, a noção de religião surge para designar certo âmbito delimitado da experiência humana num contexto em que a religião deixa de desempenhar o papel de amálgama capaz de dar unidade às diversas áreas da vida. Essa leitura da modernidade constitui-se como temática de fundo importante para as considerações de Tillich. 
Enfim, uma primeira face do conflito se deve ao fato de que a filosofia tende a conceber, no conceito de religião, a "religião" como mero produto cultural humano. Mas, a "religião" entende a si mesma como transcendente a essa limitação, uma vez que se remete ao incondicional Ao não se atentar para o caráter peculiar da religião, a filosofia não faz da "religião" seu objeto, mas, no limite, o ser humano, perdendo a especificidade de seu tema. Nesse caso, já não é a religião enquanto tal que ocupa a filosofia da religião, mas outra coisa passa a ocupar esse lugar: a cultura, o ser humano, a consciência, a sociedade, a psiquê etc. Nota-se quão complexa é o entendimento de que a filosofia da religião tem por objeto a religião. O seu objeto parece sempre lhe escapar. De modo claro, Tillich expressa o impasse ao qual a filosofia da religião chega com as seguintes palavras: "Se não observa o pretendido caráter revelado da religião, seu objeto [Objekt] se lhe escapa e não se está falando de uma religião efetiva. Se, por outro lado, reconhece a revelação, se torna teologia" (TILLICH, 1987, p.117-118).

A última frase da citação acima, entretanto, chama a atenção para a outra face do problema. Se a filosofia abdica de sua vontade de generalização e se atenta à especificidade da religião, ao seu apelo a uma revelação, ela se perde enquanto âmbito do conhecimento. Em termos mais claros, se a filosofia da religião escuta atentamente seu "objeto", no que ele reclama de exclusivo, auto-suficiente, singular, incondicional e absoluto acaba por se converter em teologia. Desse modo, não se tem mais filosofia da religião. A palavra teologia não é unívoca. Há várias definições e concepções de teologia. Nos textos desse período, Tillich parece trabalhar com um conceito mais estreito e outro mais lato (teologia filosófica). Nesse ponto da sua argumentação, ao que tudo indica, Tillich entende que teologia seria uma ciência da revelação (TILLICH, 1987, p. 118), que se dedica à interpretação dos textos que se considera sagrados e normativos dentro de determinada tradição religiosa. Ela se move num círculo mais restrito do que a filosofia, pois pressupõe uma manifestação concreta da religião numa revelação.

Diante dos problemas suscitados pelo objeto à filosofia da religião, ela fica entre a cruz e a espada: se permanece fiel aos princípios filosóficos perde seu 
"objeto"; caso preserve a especificidade seu tema, converte-se em teologia e, portanto, acaba por se dissolver enquanto âmbito do saber.

Ainda que diste temporalmente quase um século, bem como se filie a outra tendência filosófica, problemática similar é levantada pelo fenomenólogo francês Jean-Luc Marion. Ele entende que a religião alcança sua forma mais acabada na revelação. Isto é, quando algo transcendente se manifesta experimentalmente ou traduzindo numa linguagem mais próxima de Tillich, quanto o incondicional irrompe no âmbito do condicionado. No entanto, acrescenta ele: na filosofia moderna, tudo aquilo que não é capaz de dar conta de sua razão (e, portanto, não é conceitualizável) não é assumido como legítimo. Está em operação aqui o princípio da razão suficiente, formulado no enunciado: Nihil est sine ratione. Por esse motivo, Leibniz, Malebranche e Spinoza recusaram tanto os milagres quanto a possibilidade de uma revelação. "Ou a religião entende ser metafisicamente legítima e deve se submeter à exigência do princípio de razão, isto é, se circunscrever aos limites da simples razão, e assim finalmente repudiar a revelação na medida em que essa escapa por definição à dominação do conceito, da causa e da razão. Ou a religião entende ser fiel à revelação e à toda razão, a ponto de se fazer excluir da racionalidade metafísica sob o apelido de Schwärmerei (Quimera)" (MARION, 2010, p.17). Somente se a religião se reconhece como fenômeno entre outros, que se enquadra nos limites estabelecidos pelas categorias da subjetividade, terá direito de cidadania filosófica. Mesmo nos casos em que a revelação não é interpretada como oposta à razão (em Hegel e Schelling, por exemplo), ela deve ser traduzida em conceitos, submetendo-se assim aos limites da razão.

Nem mesmo a fenomenologia, da qual Marion se reconhece herdeiro, escapa dessa limitação. Por meio da redução transcendental, a fenomenologia encontrou modo de abordar os fenômenos religiosos sem apelar à transcendência, inscrevendo-se assim numa abordagem que se atém aos limites da imanência da consciência. Não cabe a ela questionar a verdade do objeto da experiência religiosa. 
Ao invés de se ocupar dos entes transcendentes, a fenomenologia da religião se empenha em trazer à luz o modo como o sujeito tematiza esses “objetos”. Assim, por exemplo, não importa se Deus existe ou não; o que interessa é que tem uma subjetividade que tematiza essa noção, constituindo uma rede de sentido a partir dela. Em poucas palavras, o que importa não é a existência ou não de Deus, mas que há seres humanos que formam referenciais de interpretação do mundo a partir daqui. O ponto não é falar do objeto em si (Deus), mas como ele é tematizado por uma consciência (Ego). Esse movimento permitiu converter a religião em fenômeno, tornando-a passível de análise. Mas, de novo, a religião deve se ater a limites previamente estabelecidos. No caso da fenomenologia, destaca Marion, o ego e o horizonte determinam as fronteiras.

Para o filósofo francês, a redução fenomenológica permitiu ganho importante na abordagem da religião. Descortinou-se nova interpretação que escapava aos reducionismos das concepções da religião como mera projeção (seja de ordem social, ideológica, psicológica ou mesmo de alienação da consciência) ou da religião como função social. De maneira similar, também se evitou o recurso a entes transcendentes. Mas, é de se perguntar, se justamente aqui a religião perde sua especificidade, que consiste em: “anunciar um acontecimento, enunciar uma palavra que ultrapassem as condições de possibilidade da experiência e transgridam as exigências do princípio de razão” (MARION, 2010, p.18). De modo similar a Tillich, é de se perguntar se as reduções fenomenológicas não deixam escapar justamente aquilo que pretendem preservar: a religião, entendida como esse irromper do incondicional no condicionado.

Por outro lado, como tratar fenômenos especificamente religiosos, que não se deixam descrever, visto não se limitarem às condições de possibilidade colocadas pelo ego? Reconhecer a impossibilidade de objetivá-los não seria decretar a morte da fenomenologia e da filosofia da religião3? Se os fenômenos religiosos não são reduzidos às condições de possibilidades do sujeito (portanto, tidos como

\footnotetext{
${ }^{3}$ Seguindo os passos da conferência de Heidegger, Fenomenologia e teologia (2008), é possível compreender fenomenologia nesses contextos como similar à filosofia. Além disso, para Marion, a fenomenologia representaria um caminho de superação da metafísica.
} 
objetiváveis), como podem eles se converterem em objetos do conhecimento? Em poucas palavras, Marion (próximo a Tilllich, ainda que em chave fenomenológica) se questiona em que medida a fenomenologia, entendida como método que adota a redução transcendental, faz justiça à religião4. A questão é enunciada por ele nos seguintes termos: "ou bem [na filosofia da religião] se trata de fenômenos definíveis objetivamente, mas que perdem sua especificidade religiosa, ou se trata de fenômenos especificamente religiosos, mas que não podem se descrever objetivamente" (MARION, 2010, p. 37). Assim, um fenômeno religioso, no sentido pleno, deve tornar visível aquilo que não pode ser reduzido à mera objetividade.

Enfim, como se pode notar a questão da relação entre filosofia da religião e seu objeto permanece atual e complexa, revelando-se como central para a filosofia e fenomenologia da religião. Ainda que Marion tenha claramente como proposta o desenvolvimento de uma fenomenologia que supere a filiação às filosofias do sujeito e da consciência presentes em Husserl e Heidegger, chama a atenção como se coloca problema similar a Tillich em relação à filosofia da religião: como tratar da religião sem que a filosofia abdique de sua vocação, mas também sem perder a especificidade de seu "objeto"?

\section{A solução de Tillich}

A solução elaborada por Tillich em resposta a essa problemática passa pelo método denominado por ele de metalógico. Não é objetivo desse texto desenvolver em maiores detalhes esse método (Cf. HIGUET, 2011). Cabe dizer que Tillich parte de uma relação entre pensamento e ser. Nesse momento de sua experiência intelectual, em que busca articular sua herança idealista com elementos do neokantismo, Tillich concebe o pensamento como lugar das categorias. É a partir

\footnotetext{
${ }^{4}$ Curiosamente, em $O$ visível e o revelado, Marion cita o caso de Rudolf Bultmann, que teve contato com Heidegger. O teólogo, segundo Marion, tentou definir a revelação a partir do eu e de suas vivências. "O método fenomenológico não se aplica aqui à teologia, a não ser para reduzir o revelado à vivência do revelado, portanto para ocultar o revelado que se revela. A redução fenomenológica provoca a demitologização, e a sola fides (somente a fé) reduz a transcendência reveladora à imanência real da consciência" (MARION, 2010, p.26).
} 
delas que se pode conferir sentido, valendo-se da lógica, que se constitui de leis que regem o pensamento. Mas, a restrição a esse âmbito das categorias (note-se a presença do neokantismo) conduz ao formalismo vazio. Caso se permaneça apenas no interior do formalismo do pensamento crítico, o ser acaba se configurando apenas dentro dos limites estabelecidos pelas categorias lógicas do sujeito. Falta o algo sobre o que estas categorias devem atuar e que extrapolam em muito o sujeito. Nesse aspecto que o método é metalógico. Não é negação da lógica. Mas, na tentativa de se evitar o formalismo, reconhece o ser, entendido como aquilo que extrapola as categorias do pensamento. Sendo assim, há um doador de sentido (pensamento) e um receptor de sentido (o ser, i.e., as coisas). Nessa relação, o elemento doador de sentido dirige a forma; o elemento receptor produz a compreensão ou a intuição da substância (Inhalt). O método metalógico supera o logicismo do método crítico puro. O receptor de sentido é intencionado não apenas pelo conhecimento, mas por todas as funções de sentido. Dessa discussão, importanos aqui o seguinte: para Tillich, conhecimento implica em forma e substância.

O pensador alemão parte do pressuposto de que toda ação espiritual é significativa, uma vez que toda a atuação do Espírito (Cf. TILLICH, 1981, p.137ss)5 se comporta como atualização do sentido. No entanto, a pergunta pelo sentido pode remeter para uma regressão infinita. Pode-se questionar pelo sentido do sentido. A resposta a esta pergunta apontaria para outro sentido e, assim, sucessivamente. Não caberia, segundo Tillich, tentar encontrar um sentido que se colocaria num lugar mais elevado, visto que ainda se estaria movimentando no âmbito do sentido. A fim de evitar esse círculo vicioso, Tillich entende que o sentido deve encontrar um fundamento. Esse fundamento é precisamente o que ele denomina de Incondicional. Ele não pode ser tido como mais um sentido, mas se difere justamente por ser o fundamento de todo o sentido.

\footnotetext{
${ }^{5}$ No que concerne a esse aspecto, Tillich se mostra bastante dependente do idealismo alemão. No seu sistema das ciências, ele concebe três tipos de ciências. Em primeiro lugar, há aquelas que lidam com o pensamento (lógica, matemática). Ao lado dessas, há as ciências do ser que se ocupam dos entes (ciências empíricas como direito, física, geologia etc). Por fim, há as ciências do Espírito (ou ciências humanas). Aqui, espírito é "a auto-determinação do pensamento no interior do ser" (TILLICH, 1981, p.137), ou seja, é o modo de pensar daquele que existe. O ser humano, enquanto existente, é formado pelo pensamento, mas também absorvido no interior do ser. Essa dinâmica e tensão, entre pensamento e ser, leva à valoração das coisas que pode dirigir-se para o universal e/ou se realizar no particular. Por isso, o Espírito se articula sempre com sentido, com ato de atribuição consciente de sentido. É justamente esse ato que se entende aqui por ação espiritual.
} 
Ao mesmo tempo em que é fundamento de sentido, o incondicional é também abismo. O seu aspecto abismal se encontra no fato de que ele sempre está além (transcende) toda forma condicionada de sentido. Caso se admitisse que uma forma finita fosse capaz de conter em si a totalidade do incondicional, se estaria diante de flagrante absurdo. Para ser reconhecido enquanto incondicional, esse fundamento deve estar além de toda forma finita (sendo abismo), ao passo que lhe concede também fundamento, enquanto substância que preenche e dá sentido à forma finita.

Em outros termos, toda ação do Espírito, enquanto ação de sentido, é composta de forma e substância (Inhalt). É justamente nesta intersecção que Tillich encontra o elemento de síntese entre religião e cultura, entre o conceito de religião e a religião. Nas suas palavras,

Quando a consciência se dirige para as formas particulares de significado e sua unidade, tem a ver com cultura; se está dirigida até o sentido incondicional, a substância de sentido, se está frente à religião. A religião é a orientação ao incondicional, e a cultura é a orientação até as formas condicionadas e sua unidade. Essas são as determinações mais gerais e formais da filosofia da religião e da filosofia da cultura. Mas essas determinações são inadequadas. A forma e a substância se co-pertencem; não tem sentido postular uma sem a outra. Toda ação cultural contém o sentido incondicional; baseia-se no fundamento do sentido; na medida em que é um ato significativo, substancialmente, religioso (TILLICH, 1987, p. 134).

Desse modo, o que classificada certa ação como cultural ou como religiosa não é especificamente seu conteúdo, mas sua orientação, sua intencionalidade. No caso da religião, a orientação se dá rumo ao incondicional que, nesse caso, é identificado com a substância. Já no âmbito da filosofia da cultura, a intencionalidade se dirige para as formas culturais finitas. Esse modo de dizer, entretanto, é apenas didático, uma vez que forma e conteúdo não se dão separadamente. Assim, o incondicional não pode ser atingido imediatamente (no sentido de sem mediações). Somente por meio das formas culturais se pode ter acesso a ele. No entanto, a correta abordagem das formas finitas obriga a que se leve em consideração o seu fundamento no incondicional. Como se pode notar, há 
interdependência intrínseca entre ambos: somente se pode ter acesso ao incondicional por meio das formas finitas. As formas finitas, por sua vez, somente adquirem seu sentido pleno e religioso quando analisadas na perspectiva do incondicional.

Desse modo, para Tillich, a religião não pode ser tida como uma função de sentido ao lado de outras. Ela não é apenas uma função do espírito, como o é a estética, a ética, o conhecimento, etc. Uma vez que a religião se dirige ao incondicional, àquilo que se constitui como fundamento/abismo de todo sentido e que está na base dessas funções, a religião permeia todos os demais âmbitos.

Em suma, o caminho de Tillich é o seguinte: toda ação espiritual é significativa. Enquanto ação de sentido, ela possui uma forma e uma substância. Essa substância se articula com aquilo que é incondicional, isto é, fundamento/abismo de todo sentido. Esse fundamento do sentido, tido como incondicional, tem conotação religiosa, pois se aproxima daquilo que posteriormente se denominará de preocupação última (Ultimate Concern). Conclui-se, portanto, que toda ação espiritual, sendo significativa, é religiosa. Para Tillich, portanto, religião não se constitui como sistema de crenças ou se articula com determinada instituição. Antes, religião é a orientação para o incondicional (fundamento e abismo de sentido) que se dá via formas culturais finitas. Com isso, preserva-se o caráter incondicionado do incondicional, sem separá-lo das formas finitas da cultura. A religião, portanto, não se constitui como uma função ao lado das outras. Caso isso venha a ocorrer, o incondicional perde seu caráter mais próprio. Se a religião é tida como estando acima da cultura, a religião se torna em apenas mais um sentido. Mesmo que seja o mais elevado, a religião é meramente mais um elo na corrente de sentidos. Por fim, caso se conceba a religião em oposição à cultura (como ocorre no iluminismo), a unidade de sentido é destruída, de modo que a religião ou a cultura é considerada como absurda, visto que elas se auto-excluem. Desse modo, a religião se mostra como dimensão de profundidade em relação à cultura. Ela é a substância que dá direção às formas da cultura, concedendo-lhe sentido. 
Enfim, como esta relação entre forma e substância ajuda a resolver o problema da abordagem da religião por parte da filosofia da religião? Como se pode notar, não se trata de inserir uma cisão entre cultura e religião. A religião somente pode ser considerada a partir da cultura (das formas finitas), isto é, da produção cultural de uma subjetividade. Por outro lado, as formas da cultura adquirem sentido na sua orientação ao incondicional (mesmo quando não admitem explicitamente essa dependência). Ao se dar esse segundo passo, é possível considerar a religião em sua peculiaridade (o que não implica na perda do objeto), sem incorrer numa teologia, enquanto hermenêutica de uma revelação. Acredita Tillich que por meio dessa articulação entre cultura e religião preserva-se a vocação da filosofia, bem como a singularidade do objeto da filosofia da religião.

No entanto, uma pergunta que ainda persiste é: se Tillich parece obter relativo sucesso ao preservar o caráter específico da religião, ele não acaba incorrendo no outro extremo, isto é, na redução da filosofia da religião em teologia? Em outros termos, o preço pago para se preservar a religião de sua redução à mera função ao lado das outras, não é justamente incorrer numa teologia? Nesse caso, não se pensa numa teologia em sentido restrito, como hermenêutica de textos religiosos normativos de uma tradição específica. Pela argumentação acima resumida, fica claro que Tillich não se vale do recurso a uma revelação especial para manter a pertinência da religião. Eliminando, desta feita, essa compreensão mais restrita de teologia em favor de uma teologia filosófica, a questão tem pertinência. Se a religião é a substância da cultura, ela é pressuposta em todas as manifestações de sentido. A filosofia é, por sua vez, uma dessas funções de sentido. Ela pode, enquanto filosofia, voltar-se apenas para as formas culturais finitas. No entanto, enquanto filosofia da religião (filosofia primeira que lida com causas e princípios), ela deve considerar o incondicional. Aqui cabe um esclarecimento. Tillich entende que a filosofia da religião, uma vez que lida com incondicional que é fundamento, seria filosofia primeira. Ela não é filosofia segunda, como se trata-se 
da religião como um fenômeno ao lado de outros. Mas, ao se voltar para o incondicional trata daquilo que é fundamento, das causas e princípios ${ }^{6}$.

Sendo assim, a filosofia da religião acaba se configurando como filosofia religiosa da religião. Em outros termos, a filosofia da religião não é apenas genitivo objetivo, mas genitivo subjetivo. A filosofia não possui apenas a religião como objeto, mas a filosofia da religião é, antes de tudo, religiosa. Isso porque a religião não é apenas uma esfera da produção humana ao lado das outras, mas é a base a partir de onde a cultura se constitui. Em termos mais claros, a filosofia da religião não é filosofia segunda (que lida com um âmbito específico de objetos), mas filosofia primeira (que lida com o fundamento). Nos próprios termos de Tillich, " $a$ análise filosófica é conduzida até ao ponto onde se percebe a si mesma, com toda a cultura, como expressão do religioso" (TILLICH, 1987, p.142).

Esse elemento teológico da abordagem de Tillich pode ser percebido nos textos que temos utilizado como base. Em primeiro lugar, em $A$ superação do conceito de religião pela filosofia da religião, associa, sem maiores explicações, o incondicional a Deus. E, a partir disso, pondera que "a religião não é o princípio $e$ o fim e o meio de todas as coisas, mas Deus" (TILLICH, 1987, p.90). Em outros termos, o incondicional é tomado como sinônimo de Deus. E a filosofia da religião, enquanto direcionamento para o incondicional, deve, ao final (ou de início), reconhecer a impossibilidade de abandonar seu fundamento, o incondicional, ou seja, Deus.

Em segundo lugar, cabe lembrar que a intenção do sistema das ciências, exposto numa publicação de 1923, além de se inserir num importante debate do início do século XX, é resgatar o lugar da teologia no âmbito do saber científico. Nesse sentido, é sintomática a afirmação de Tillich de que, na Idade Média, a teologia era considera da rainha das ciências. Nesse contexto, ela continha em si o direcionamento ao incondicional, sem menosprezar as formas culturais. No

\footnotetext{
${ }^{6}$ Esse debate, se a filosofia da religião é filosofia primeira (lida com o fundamento do ser) ou se é filosofia segunda (aborda uma região específica da cultura que se denomina de religião) é um debate que se estende aos dias atuais (cf. GRECO, 2009, p.17-30). Para Tillich, a filosofia da religião por se ocupar com o incondicional é, claramente, filosofia primeira. Ela não interpela apenas uma parte da realidade, mas o seu fundamento.
} 
entanto, ao final desse período histórico, há dissociação em relação ao incondicional. Afirma-se a autonomia da razão, de modo que a religião passa a ser associada à heteronomia. Com essa alteração, a teologia perde seu trono, para compartilhar um lugar ao lado (ou mesmo abaixo) de seus antigos súditos. E, "Isto se tornou desastroso para ela, porque contradiz a natureza da teologia ser uma ciência entre outras" (TILLICH, 1981, p.206).

Os resultados disso podem ser vistos ainda no século $\mathrm{XX}$, mediante duas compreensões correntes de teologia. De um lado, a partir da perspectiva secularracional, teologia é uma espécie de ciência da religião do cristianismo, da fé, etc. Seu mérito reside em reconhecer que Deus não pode ser considerado como objeto ao lado de outros, como se pudesse haver uma ciência de Deus ao lado de outras ciências. Mas, seu dilema reside no fato de que os demais objetos já estão sob o domínio de outras ciências, não restando muitas opções para ela. Por outro lado, há a concepção de teologia como religious-heteronomous. Nesse caso, busca-se preservar a independência desta ciência, com a condição de dissociá-la da cultura. A teologia, numa busca de retornar ao seu antigo lugar, emprega a estratégia de se impor frente à autonomia conquistada, como que tentando retomar seu lugar à força. Mas, nesse caso, pode conduzir à dissolução, uma vez que parte do pressuposto do abismo existente entre cultura e religião, considerando os símbolos de determinada tradição como absolutos e dissociados das formas culturais. Ao fazê-lo, entra em conflito com os processos autônomos das demais áreas, reforçando (e com razão) as suspeitas de heteronomia que pesam sobre ela, visto que não considera que os símbolos metafísicos são dependentes dos processos autônomos.

Nesse quadro, o sistema das ciências busca atribuir um lugar para teologia que atenda a duas demandas. De um lado, ela deve reconhecer sua interdependência em relação à cultura, às formas finitas oriundas do processo autônomo que caracteriza a modernidade. A teologia não pode querer usurpar o lugar outrora ocupado, como rainha das ciências, sem manter nenhum tipo de 
relação com seus antigos súditos, como tentando obter seu trono de volta por meio de um golpe. Por outro lado, enquanto ainda guarda algo daquela antiga nobreza, ela tem papel de legisladora. Visto lidar com o incondicional, ela desempenha papel normativo; não somente para a filosofia da religião, mas para as ciências humanas como um todo (TILLICH, 1981, p. 207-208). Enfim, pode-se notar como nessa percepção há uma sobreposição entre teologia e filosofia da religião.

O que resulta desta discussão? Tillich tenta desenvolver abordagem da religião que não perca a especificidade do seu objeto. Nesse sentido, por meio do par forma e substância (conteúdo) busca articular o incondicional com o condicionado. Aquele se mostra como prious, fundamento anterior à distinção entre sujeito e objeto, que fundamenta a produção de sentido. No entanto, o incondicional se torna presente por meio das formas finitas. Por vezes, elas não reconhecem sua dependência do incondicional. Isso, no entanto, gera situação de fragmentação, que pode ser superada pelo religioso, entendido como a orientação rumo ao incondicional, que está em todas as formas culturais (fundamento), sem se reduzir a eles (abismo). Desse modo, no reconhecimento da interdependência, Tillich busca manter a pertinência do conceito de religião, desde que visto à luz do incondicional. No entanto, ao tentar resgatar o "objeto" da filosofia da religião, por mais que tenha consciência dessas dificuldades, acaba desembocando na teologia7.

\footnotetext{
7 É importante ressaltar que Tillich toma ciência da amplitude do problema apenas no texto de 1925, intitulado Filosofia da religião. Se tomamos três textos, escolhidos por ele anos depois para serem traduzidos para o inglês e comporem um livro intitulado What is religion?, isso se torna bastante evidente. Cronologicamente, o primeiro texto desse volume se intitula Para uma ideia de uma teologia da cultura (1919). Sem entrar na riqueza das propostas, essa prelação aponta a necessidade de se desenvolver uma teologia da cultura, tendo por problema de fundo a fragmentação da cultura em esferas sociais autônomas. No segundo texto, $A$ superação do conceito de religião na filosofia da religião, como o próprio título indica, Tillich está mais preocupado em mostrar como o conceito de religião é redutor da religião vivida. Portanto, deveria ser superado na filosofia da religião. Outro aspecto para o qual vale chamar a atenção é que, nesse texto, Tillich emprega os termos Deus e Incondicional como sinônimos, sem oferecer ao leitor argumentos que legitimem essa passagem de um conceito ao outro. Isso revela, portanto, como sua reflexão tende a buscar salvar a religião de abordagens reducionistas. Por fim, no artigo $A$ filosofia da religião (1925), Tillich retoma o problema da redução da religião no conceito religião, mas vai além: por outro lado é preciso também evitar o extremo de se dissolver a filosofia da religião na teologia. Pelo que pudemos averiguar, essa problemática é colocada de maneira mais clara por Tillich nesse texto, demonstrando que é preciso equilibrar a reflexão. Não somente é preciso preservar o caráter peculiar da "religião", mas também é importante estar atento aos procedimentos da filosofia da religião para que ela não se perca. De todo modo, ressalta-se que o problema em toda sua amplitude é elaborado apenas em 1925 , mostrando que somente aqui ele se dá conta de que é preciso evitar também o outro extremo.
} 


\section{A solução de Marion}

A fim de responder ao impasse que a religião coloca à filosofia da religião, Marion desenvolve a noção de fenômeno saturado. Em poucas palavras, essa classe de fenômenos permitiria abordar aspectos da religião sem incorrer em sua objetivação, preservando seu caráter especificamente religioso. Mas, antes de notar como os fenômenos saturados podem responder a esses impasses, há questões que se impõem. A primeira é: o que se compreende por fenômeno saturado? Em segundo lugar, como os fenômenos saturados são possíveis? Como se pode falar de fenômeno sem colocar o sujeito como constituinte deles? E, por fim, como a fenomenologia pode se apropriar desse tipo de fenômenos, uma vez que não são objetiváveis?

Para que se compreenda o estatuto dos fenômenos saturados é importante que se faça uma comparação com outros tipos de fenômenos, que são classificados segundo a relação entre conceito (significação) e intuição. Essa relação é retomada a partir de Husserl, que estabelece como forma de conhecimento paradigmática a completa adequação entre significação e intuição. Em suas palavras, "A experiência do acordo [Zusammenstimmung] entre a significação e o que se presenta em si mesmo, isto é, entre o sentido atual de uma proposição e de um estado autodoado de coisas, é internamente evidente; a ideia desse acordo é verdade, cuja idealidade é também a sua objetividade”(HUSSERL, 1975, Hua XVIII, p.193-194). Fica mais claro que se compreende por verdade e por evidência: há acordo entre o que se espera e o preenchimento na intuição, entre significado e intuição na autodoação originária.

Uma vez que a significação é anterior, ela pode ser preenchida em diversos graus, permitindo vislumbrar, para Marion, três classes de fenômenos. Em primeiro lugar, há fenômenos que não são preenchidos por nenhuma intuição. 
Marion lembra as idealidades matemáticas como prova de que a significação é anterior à intuição. Apesar dos conceitos matemáticos não encontrarem preenchimento adequado na intuição, são tomados como os mais evidentes. A noção geométrica de espaço ou do círculo perfeito, por exemplo, não encontram preenchimento na intuição, mas isso não as torna menos evidentes. Há, nesse caso, um excesso da significação em relação à intuição. “A compreensão matemática (...) é propriamente caracterizada por sua capacidade de pensar significações que permanecem irredutíveis a qualquer intuição" (MARION, 1998, p.24). É claro que a significação depende daquilo que significa, a fim de não cair na total arbitrariedade. Mas afirmar isso não significa dizer que há dependência da significação em relação à intuição, pois, a

significação oferece um 'conteúdo' que é caracterizado como um 'conteúdo ideal', algumas vezes entendido 'como sentido intencionado' ou como sentido, às vezes identificado com um 'conteúdo teórico' ou com um 'conteúdo lógico' - em todos os casos, 'a essência da significação não é vista por nós, não na experiência de conferência da significação, mas em seu conteúdo, que presenta uma unidade intencional idêntica” (MARION, 1998, p.28).

Enfim, nessa primeira classe de fenômenos, há excesso da significação em relação à intuição, a ponto de dispensá-la.

Em segundo lugar, há outro tipo de fenômeno que se configura como o mais frequente em nossa experiência cotidiana. Nesse caso, a significação recebe a intuição; mas a intuição nunca preenche totalmente a significação. Há, novamente, excedente de significação e pobreza de intuição. A intuição é pobre e incapaz de preencher totalmente a significação. Nesse sentido, a verdade e a evidência, como completa adequação entre significação e intuição, somente pode ser tomada como caso paradigmático, mas que raramente ocorre. Uma vez que há pobreza na intuição, a significação pode intencionar, prever, suportar e objetivar o que aparece. Afinal o que é intuído sempre se dá dentro dos limites que a significação estabelece. Aquilo que é intuído se insere no horizonte delimitado pela significação, sendo possível apreendê-lo de modo pleno. A ocorrência mais comum desse tipo de 
fenômeno não é meramente acidental. Antes, para que um determinado fenômeno possa ser apreendido num determinado horizonte pelo ego, ele deve ser finito, isto é, delimitado. É justamente esta penúria da intuição e o excesso da significação que permite com que o sujeito apreenda esse fenômeno nos simples limites de suas categorias podendo, assim, objetivá-lo.

Como se pode observar, esses dois tipos de fenômenos possuem elementos comuns. Ambos partem do princípio de que há certa defasagem intuição em relação à significação. Novamente, cabe enfatizar que é justamente isso que permite o enquadramento da intuição dentro dos limites da significação. Esta "falha" da intuição se deve a uma necessidade interna, uma vez que todo fenômeno deve se inscrever num horizonte, é preciso que esse horizonte seja mais amplo que a própria intuição. Caso contrário, o horizonte não poderia comportar aquilo que aparece dentro de seus limites.

A partir desses dois tipos de fenômenos, Marion sugere um terceiro, não previsto nem por Kant nem por Husserl. Esse seria possível na situação em que há excesso de intuição em relação à significação. Em outros termos, a intuição excede e satura a delimitação imposta pela intencionalidade. Em suas palavras, fenômenos saturados são aqueles

onde a dualidade entre intenção (significação) $e$ intuição (preenchimento) certamente se mantém, assim como a correlação noética-noemática, mas onde, em contraste com fenômenos pobres e comuns, intuição se dá excedendo o que o conceito (significação, intencionalidade, intuito, etc) pode pressupor dele e mostrar (MARION, 2002, p.112).

A intuição rompe os limites estabelecidos pela significação uma vez que se mostra excessiva, isto é, mais ampla que as condições de possibilidade previamente estabelecidas pela intencionalidade. Isto é, o que Marion propõe é a possibilidade de fenômenos que justamente subvertam os princípios que regiam os dois fenômenos anteriores. Ao invés de partir do princípio de que a intuição é pobre e pode ser apreendida plenamente pela significação, supõe que haja um excesso na 
intuição a ponto de romper com os limites previamente estabelecidos pela significação.

Ao contrário do que se poderia imaginar, fenômenos saturados são mais comuns do que se imagina. Jean-Luc Marion cita alguns exemplos. Em Descartes, a ideia de infinito se mostra como percepção de um fenômeno desse tipo. Mesmo em Kant, deparamo-nos com o efeito do sublime, expresso na ideia estética. Há aqui intuição para a qual não se pode encontrar conceito adequado. Como se pode notar, não é mais a intuição que falha. É o conceito que se mostra inadequado para enquadrar a intuição e transformá-la em objeto.

Há certa tensão entre significação (conceito) e intuição (conteúdo), que leva a uma variação do grau de intuição no fenômeno. Portanto, retomando as três classes de fenômenos pode-se notar um crescendo: parte-se de uma situação de mínimo de intuição para sua consideração como imensurável. Esse aspecto imensurável e excessivo da intuição constitui os fenômenos como saturados, como trazendo em si excesso de intuição não passível de ser emoldurada pela intencionalidade. Ela extrapola os limites que a significação pretende impor aos fenômenos.

\section{II}

No entanto, a mera afirmação de fenômenos saturados não garante sua plausibilidade. É importante ressaltar que a intenção de Marion, ao menos quando se move no campo estritamente fenomenológico, não é pontuar a atualidade dos fenômenos saturados, mas apenas garantir sua possibilidade. Quer dizer: não é função da fenomenologia mostrar a efetividade desse tipo de fenômenos. Mas, antes, apenas mostrar que é preciso alargar a fenomenologia para que se reconheça que fenômenos dessa natureza são possíveis.

No texto intitulado O fenômeno saturado, Marion aponta a possibilidade dos fenômenos saturados retomando as categorias do entendimento de Kant (quantidade, qualidade, relação e modalidade) (MARION, 2010, p.57ss). Marion 
busca descrever como essas categorias se portam quando se está diante de um excesso de intuição. O objetivo de seu texto é promover certa inversão na concepção kantiana. Se Kant pensava sempre essa relação a partir dos fenômenos comuns, isto é, aqueles dotados de certa deficiência na intuição, o que acontece quando se está diante de fenômenos que excedem as categorias do entendimento? Não cabe aqui, por uma questão de espaço, retomar os passos argumentativos de Marion, mas apenas indicar suas conclusões. Com relação à quantidade, o fenômeno saturado se mostra como imprevisível por parte das categorias. Sendo imprevisíveis, os fenômenos saturados geram admiração. Marion cita como exemplos desse tipo de experiência, fenômenos históricos puros (MARION, 2010, p.73). Com relação à qualidade, o fenômeno saturado atinge uma grandeza desmedida, que ultrapassa todas as antecipações possíveis. Isso provoca o deslumbramento no olhar, que se depara com um visível que não pode suportar. Exemplos desse tipo de fenômeno é o deslumbrante brilho de uma obra de arte. Pertinente à categoria da relação, o fenômeno saturado se mostra como absoluto, tendo em vista que ele se furta a toda analogia com a experiência, não respeitando a unidade da experiência. Exemplo desse tipo de fenômeno é a intimidade de minha própria carne. Por fim, quanto à modalidade, o fenômeno se mostra como incodicionado, uma vez que ele escapa da delimitação que um horizonte pode prescrever. Exemplo desse tipo de fenômeno é a face do outro.

Em Husserl, encontra-se algo similar a Kant, conforme expresso no princípio dos princípios da fenomenologia: "Toda intuição doadora originária é uma fonte de legitimação do conhecimento, tudo que nos é oferecido originariamente na 'intuição' (por assim dizer, em sua efetividade de carne $e$ osso) deve ser simplesmente tomado tal como ele se dá, mas também apenas nos limites dentro dos quais ele se dá”(HUSSERL, 2006, §24, p. 71). O que ocorre aqui? Em primeiro lugar, a intuição se atesta a si mesma. Desse modo, ela não precisa mais se justificar com base no princípio da razão, recorrendo a uma causa de matriz metafísica. Mas, essa intuição se dá dentro de certos limites, ou seja, segundo um horizonte previamente fixado pela subjetividade. Há aqui certa 
ambiguidade: Husserl parece indicar que a intuição se mostra por si. Mas, ao mesmo tempo, ela deve se dar dentro do horizonte estabelecido pelo ego. Desse modo, pontua Marion, “'O princípio de todos os princípios’ liberta, certamente, pela intuição originariamente doadora, os fenômenos do dever de dar uma razão suficiente de suas aparições. Mas não pensa esta doação senão a partir de duas determinações que ameaçam o seu caráter original - o horizonte e a redução" (MARION, 2010, p.44).

Como observado, a noção de fenômeno pressupõe um ego. No caso de Kant, um fenômeno que não se ajustasse às condições de possibilidade de conhecimento do sujeito não seria objetivável. No caso de Husserl, esse ego se torna fundamental. Com a redução fenomenológica, Husserl mostra em que medida o domínio da pura consciência é o da constituição de sentido. Em outros termos, Husserl supera a dicotomização, que vigorava nas ciências desde Descartes, que cinde entre sujeito (interioridade) e objeto (exterioridade). Agora, o sujeito se torna totalidade e o mundo, parte dependente do sujeito.

Para Marion, esse mesmo tipo de redução ocorreria também em Heidegger, revelando as tendências subjetivistas presentes em parte de sua reflexão filosófica. Se Heidegger emprega o termo Stimmungen para vivências ou Dasein para ego, isso não muda radicalmente as coisas. Na leitura de Marion, Ser e tempo ainda está sob o ditame da redução fenomenológica guiada pelo ego. $\mathrm{Na}$ verdade, o movimento heideggeriano de situar a intencionalidade no mundo, falando de um ser-no-mundo, nada mais seria do que a radicalização dos pressupostos fenomenológicos husserlianos, não havendo real ruptura. Ainda, a abertura do ser se dá na base e na dependência da abertura do Dasein (MARION, 2010, p. 30-31; 1998, 77-107).

Qual o limite da concepção de Ego na fenomenologia? Para Marion, a constituição desse ego é problema não resolvido. Aqui se encontra uma lacuna bastante promissora para se pensar fenômenos para além da sua redução à subjetividade. O ego é a base da intencionalidade. Mas, como esse ego se constitui? $\mathrm{Na}$ história do movimento fenomenológico, foram várias as tentativas de resposta a 
essa questão. Husserl, por exemplo, entende que a consciência absoluta é consciência do tempo, mas ela mesma não é temporal. Sartre, inspirado pelo Heidegger de fins de 1920, menciona a transcendência do ego; Merleau-Ponty recorre ao pré-reflexivo. Mas, a constituição dessa base para os atos intencionais fica indeterminada. Em outros termos, o ego fundamenta a intencionalidade, mas se mostra incapaz de dar contas de si mesmo. A partir disso, questiona Marion: "Se o eu não restringe fenomenologicamente à possibilidade de uma revelação, não se deveria correr o risco de que talvez o eu pudesse aceder à sua própria possibilidade fenomenológica a partir de uma doação inconstituível, inobjetável e anterior - talvez mesmo de uma revelação?” (MARION, 2010, p. 32). Em outros termos, não está aqui uma brecha para se pensar um fenômeno que ao invés de ser constituído pelo ego, o ultrapassa e o constitui? É justamente isso que Marion denomina de fenômeno saturado. Ele não se limita ao que o ego coloca, mas constitui esse ego. Assim, não se poderia pressupor uma doação originária e anterior, uma doação que não pode ser reduzida à mera categoria de objeto, mas que se mostra constituinte do ego?

Em segundo lugar, mas não menos importante, há a noção de horizonte. Horizonte indica um campo de visão que abre, mas que também delimita um conjunto de fenômenos. Assim, horizonte delimita certa moldura dentro qual a intuição pode ser dada. Esses limites são determinados previamente, limitando a abordagem da fenomenologia tradicional apenas a fenômenos que podem ser tratados objetivamente. Enfim, somente se pode falar de fenômenos porque essas duas condições estão dadas: há um ego que constitui o fenômeno e há um horizonte que delimita sua manifestação, tornando esse fenômeno apreensível para esse ego. A relação com o horizonte se mostra complexa, afinal ela coloca a questão de como um fenômeno que não pode ser previsto, não é sustentado por um horizonte e é absoluto pode aparecer.

Em outros termos, qual o direito que tem um fenômeno que extrapola os limites estabelecidos pelo horizonte e pelo ego? Além do mais, se o fenômeno fosse 
mera negação do horizonte, ele não poderia aparecer, não poderia ser visto. Ele tem necessidade de estabelecer certas relações para se tornar manifesto. Nesse ponto, Marion levanta ao menos três possibilidades (HORNER, 2005, p.113ss). Em primeiro lugar, o fenômeno é visto como sendo ele mesmo o seu próprio horizonte. Ele não depende de nada previamente fixado, mas ele mesmo se coloca como o horizonte que torna possível a manifestação. É como se houvesse uma sobreposição entre o que se mostra e aquilo que possibilita com que um fenômeno apareça. Em segundo lugar, outra possibilidade de compreensão, é a de que o horizonte é espécie de contra-experiência. Nesse sentido, os fenômenos saturados não somente questionam os limites de determinado horizonte, mas de vários horizontes, pavimentando caminho para uma hermenêutica infinita ao articular vários horizontes. Por fim, ele preenche o horizonte de maneira excessiva, extrapolando a fronteiras pré-fixadas por determinado horizonte. Na tentativa de manter a independência do fenômeno saturado de qualquer horizonte, Marion pontua que mesmo nesses casos, os fenômenos saturados não se conformam aos horizontes. Antes, a revelação se apresenta no horizonte, mas, por meio do excesso, o satura. Isso quer dizer, excede a moldura previamente demarcada por determinado horizonte. Em seus próprios termos,

Ele se liberta dela [da analogia] porque não depende de nenhum horizonte. Ao contrário, quer ele o sature simplesmente, quer o divida para saturá-lo ainda mais, quer ele o exceda e se encontre rejeitado. Mas essa mesma desfiguração permanece uma manifestação. Em todos os casos, ele não depende desta condição de possibilidade por excelência um horizonte qualquer que seja. Nós o chamaremos, portanto, incondicionado. (MARION, 2010, p.66-67).

Assim, pode-se notar como a fenomenologia traz um ganho em relação à metafísica. O princípio dos princípios de Husserl apontava para um alargamento dos fenômenos, visto que não mais coloca como condição o princípio da razão. Eles já não precisam mais de uma razão suficiente ou de uma intuição correspondente para se legitimarem. Admite-se, nesse caso, uma intuição doadora. No entanto, a fenomenologia de Husserl e de Heidegger ainda estabelecia condições de possibilidade para os fenômenos com base no ego e no horizonte. A proposta de Marion é ampliar ainda mais o campo da fenomenologia, no sentido de pontuar a 
possibilidade de um fenômeno não objetivável e que, portanto, exceda o sujeito e os limites que ele estabelece. Mais especificamente para a filosofia da religião, Marion busca manter a pertinência do fenômeno da revelação que, como observado, define mais propriamente a noção de religião em sua perspectiva. $O$ fenômeno da revelação é tido como fenômeno que satura o horizonte, não somente em uma daquelas categorias de Kant, mas em todas as quatro. Assim, a revelação é fenômeno saturado por excelência: ele é excessivo com relação à quantidade, à qualidade, à relação e à modalidade ao mesmo tempo. Em outros termos, a revelação (que define o fenômeno religioso) é imprevisível, imensurável, absoluta e incondicionada. Em acordo com isso, poder-se-ia dizer que esses fenômenos são indizíveis.

\section{III}

Caso se admita pertinência de se falar em fenômenos saturados, como lidar com esses fenômenos que não podem ser reduzidos à classificação tradicional de fenômeno? Como ainda fazer fenomenologia da religião a partir dos fenômenos saturados? O que fazer com fenômenos que resistem à objetivação? $\mathrm{O}$ fato do fenômeno saturado não ser objetivável não significa que ele não seja visível. Em outros termos, afirmar a possibilidade de fenômenos saturados significa assumir que nem todos os fenômenos possam ser objetivados, ou seja, nem todos os fenômenos podem ser enquadrados nos limites impostos pelo ego e pelo horizonte. Ainda que esteja alheio a essa discussão fenomenológica mais técnica, uma passagem de um texto de Pasolini pode auxiliar aqui. Ao tratar da experiência de um de seus personagens em Teorema, ela afirma: “O pai fica olhando longamente, enternecido, aquela aparição, à qual não sabe atribuir qualquer significado - $e$, no entanto, ela também não deixa de ser reveladora” (PASOLINI, s/d, p.55) ${ }^{8}$. Em outros termos, algo é revelado. No entanto, por não ser suportado pelo ego e pelo

\footnotetext{
${ }^{8}$ Chama atenção a proximidade dessa formulação com uma oferecida por Marion sobre os fenômenos saturados: "Eu não posso ter uma visão desses fenômenos, porque eu não posso os constituir a partir de um sentido unívoco, e nem mesmo produzi-los como objetos. O que eu vejo deles, se eu não vejo nada do que é, não resulta de uma constituição que eu poderia assinalar a eles no visível, mas do efeito que produzem em mim"(MARION, 2002a, p.113).
} 
horizonte, não é objetivável a ponto de se apreender um sentido. Antes, ele coloca em suspensão o horizonte e, portanto, todo o sentido. Entrementes, a simples constatação de haver fenômenos que excedam às condições de objetividade, não significa que não haja nada de visível. Algo é visto. Mas, isso que aparece não pode ser reduzido a um objeto. O olhar vê um excesso de intuição, difícil de dominar, um excesso que não torna esse fenômeno passível de consideração ou de redução a uma objetividade domável. Em suma, o fenômeno saturado mostra algo, mas esse algo que é mostrado não pode ser emoldurado como objeto devido ao estreitamento da vista diante do que se mostra (MARION, 2002, p.215).

No entanto, daqui decorre uma questão que o próprio Marion levanta em vários momentos de sua produção (por exemplo, MARION, 2002, §22; 2010, p.162ss), indicando que aqui reside um ponto a ser refletido: se a revelação é contra-experiência, que permite que se visualize algo que não pode ser objetivado, o que fazer com esses fenômenos? Em outros termos, para que servem fenômenos que não são objetiváveis?

Em resposta a essa indagação, Marion indica duas alternativas. A primeira seria simplesmente assinalar a possibilidade desse fenômeno, sem maiores detalhamentos. Nesse caso, ele faria algo muito similar a Heidegger, uma das suas fontes de diálogo. Heidegger parte do ente para chega ao ser. No entanto, o caminho de volta do ontológico para o ôntico parece bloqueado, fazendo com que o filósofo alemão se limite a uma discursividade ontológica, com suas suspeições em relação ao método, ficando sem implicações mais imediatas para as ciências humanas. Poderia-se, desse modo, simplesmente garantir a possibilidade do fenômeno saturado sem, entretanto, fazer o caminho de volta.

No entanto, Marion ostra preferência por outra alternativa que nos interessa mais, uma vez que nela a teologia assume destacada importância. Em linhas gerais o ponto é o seguinte: se a fenomenologia deve garantir a possibilidade da revelação, cabe à teologia efetivar esta possibilidade numa concretude histórica. Como isso se dá? Nos seus textos mais fenomenológicos, é possível encontrar várias referências religiosas. Marion não hesita em empregar terminologia religiosa ou passagens 
bíblicas como fonte de reflexão filosófica ou mesmo para ilustrar algum ponto de sua argumentação. Além disso, não é muito difícil perceber que, ao fazer fenomenologia, Marion retoma vários temas da tradição teológica. O tema de Deus ${ }^{9}$, do amor, do dom, da revelação etc. são recorrentes em sua reflexão. Essa articulação de fontes, temas e a própria condução de problemas filosóficos entremeados por temas religiosos levanta inúmeras suspeitas em seus críticos. Inclusive, a desconfiança de que ele (juntamente com outros fenomenólogos franceses contemporâneos) seriam responsáveis por certa virada teológica na fenomenologia (JANICAUD, 2000) ${ }^{10}$. Diante disso, Marion se vê obrigado a se defender das acusações de misturar fenomenologia e teologia, trazendo prejuízos para ambas, buscando delimitar bem o âmbito de abordagem de cada uma. A questão é se ele, de fato, consegue manter essa distinção.

Segundo o fenomenológo, a teologia é a abordagem da revelação a partir da fé. Seu campo de atuação compreende verdades que somente podem ser acessadas por meio da fé, sendo que seu tema privilegiado é o amor. Já a filosofia, trata de fenômenos e enunciados que se restringem à razão. Por fim, ainda pontua a importância da filosofia cristã. Essa encontra e forja fenômenos que se articulam no âmbito da razão (i.e., da filosofia). No entanto, a filosofia não teria acesso as esses temas (como do amor, p.ex.) se não fosse pela intervenção da revelação. Enfim, a filosofia cristã teria a função de fazer a mediação entre a revelação strictu sensu e a filosofia. Ela consegue realizar esta tarefa por reconhecer fenômenos peculiares da revelação, sendo capaz de formalizá-los para que o trabalho filosófico seja feito a partir deles. Desse modo, a filosofia lida com objetos temáticos da razão.

\footnotetext{
${ }^{9}$ A importância de Deus é percebida quando, por exemplo, nota-se que Marion atribui a ela a passagem à pós-modernidade. No prefácio à Deus sem ser, afirma: "se nós entendemos por modernidade a imagem completa, portanto terminal da metafísica, tal como se desenvolve de Descartes a Nietzsche, então 'pós-modernidade' se inicia quando, entre outras coisas, a determinação metafísica de Deus é colocada em questão" (MARION, 1991, p. XX-XXI).

${ }^{10} \mathrm{O}$ problema de Dominique Janicaud é conceber a fenomenologia como ciência rigorosa. A partir disto, ele entende que toda abordagem da fenomenologia que não se atenha aos fenômenos, mas que busque a fonte destes fenômenos é alvo de suspeita. Na sua crítica, Janicaud sequer levanta a possibilidade de que o próprio Husserl daria abertura para este tipo de tratamento da fenomenologia com sua virada transcendental. Segundo ele, a fenomenologia de Marion se desenvolve numa dupla referência: em relação à "problemática de superação da ontologia (ou metafísica), e à dimensão propriamente teológica ou espiritual. É a junção destes dois esquemas sob o nome de fenomenologia que é contestado aqui" (JANICAUD, 2000, p.65). Enfim, a reunião entre o pressuposto heideggeriano/levinasiano de crítica à metafísica/ontologia com preocupações teológicas, encarnada claramente por Marion, é o alvo da crítica. Esse ponto de partida leva Marion, além dos problemas já apontados, a conceber certa oposição entre fenomenologia e metafísica.
} 
A teologia, com coisas da fé e a partir da fé. E, por sua vez, a filosofia cristã teria a função de estabelecer a comunicação entre elas (MARION, 2010, p.110).

No entanto, essas demarcações de território podem dar a falsa impressão de que eles não se interpenetram. É possível indicar, ao menos, duas articulações entre fenomenologia e teologia no pensamento de Marion que demonstram essa inter-relação. Ao indicar essa relação, acaba-se tocando em questão similar àquela já tratada na abordagem do pensamento de Tillich. Em que medida a filosofia da religião não é conduzida, por fim, a uma teologia? Dessa maneira, é importante ter em mente essa questão ao tratar da relação entre fenomenologia e teologia.

Em primeiro lugar, a teologia coloca problemas para a fenomenologia, de modo a levar a revisão de certos preceitos básicos. Nesse sentido, a revelação, enquanto fenômeno que não pode ser abordado pela fenomenologia nos simples limites do ego, leva ao alargamento de seus pressupostos. É a religião que leva a fenomenologia a levantar a possibilidade dos fenômenos saturados. Isso ocorre quando se atenta para o fato de que a fenomenologia não consegue empreender abordagem adequada da religião. Assim, não se trata simplesmente de abordar a religião a partir de pressupostos filosóficos, mas de notar como as noções religiosas conduzem ao repensar de conceitos filosóficos. Nesse sentido, Marion pode afirmar um movimentar-se "sem reticência de um território familiar da filosofia a fim de alterar a fenomenologia bem como a mais direta teologia cristológica” (MARION, 2002b, p. XI). De qualquer modo, nota-se a importância que Marion confere à teologia. Ela não é tida como mera hermenêutica da existência na fé e a partir da fé, mas ela mesma fornece temas e conceitos para que a filosofia possa se rever. Ela é fonte de direito e de fato de temas e conceitos filosóficos, não se configurando como mera aplicação de categorias fenomenológicas para interpretar temas restritos aos seus interesses. A teologia contribui com a filosofia trazendo novos fenômenos que, sem a ela, ficariam inacessíveis. Por outro lado, a fenomenologia pode também se constituir como método mais adequado para a teologia. A revelação, quando deixa de ser mera possibilidade para se efetivar, torna-se fenômeno. Nesse caso, a 
fenomenologia pode fornecer à teologia o aparato metodológico para lidar com isto que se efetiva.

Além dessa primeira abordagem, a relação entre fenomenologia e teologia se estabelece de outra maneira. A fenomenologia somente pode colocar o fenômeno saturado como possibilidade. Marion é bastante cauteloso quando trata de apontar que esse tipo de fenômeno é tratado apenas como possibilidade. Isso é, o objetivo de sua reflexão é manter em aberto a possibilidade de fenômenos que excedem os limites demarcados pela subjetividade. Nessa direção, ele afirma, por exemplo, “O que aconteceria fenomenologicamente, se um fenômeno não 'se harmonizasse', nem 'correspondesse' ao poder de conhecer do Eu?” (MARION, 2010, p.67). O modo de formulação (o que aconteceria...) aponta mais para uma hipótese do que para uma descrição de um estado de coisas. Isso é importante. Afinal, para Marion, a abordagem da revelação como mera possibilidade garante a demarcação das fronteiras entre fenomenologia e teologia. Isso porque a fenomenologia lida apenas com a possibilidade dos fenômenos saturados. Não cabe à ela indicar uma revelação historicamente situada. Ela garante a possibilidade da revelação, mas não diz que uma revelação em particular efetiva esta possibilidade. Ela diz que o fenômeno saturado é possível; mas não indica que ele se dá numa manifestações religiosa concreta. A teologia, por sua vez, parte da possibilidade aberta pela fenomenologia (de que há fenômenos saturados) e a atualiza. Ela diz que a revelação se mostra num texto ou numa pessoa. Desse modo, concebendo a fenomenologia como possibilidade e a teologia como efetividade, estariam demarcadas as fronteiras, mas também as mútuas dependências (MARION, 2010, p.94-95; 2002a, p.246-247).

No entanto, essas fronteiras são bem mais tênues do que aparentam. Como indicado, a teologia age sobre a fenomenologia trazendo-lhe questões que, de outro modo, não lhe seriam acessíveis. Desse modo, a teologia já se coloca no início do processo. É como se questões teológicas (teologia aqui não é tratada somente como teologia filosófica) determinassem certos caminhos para a reflexão filosófica sobre 
a religião. Ela, em certa medida, determina temas a serem tratados. Mas, para além disso, é sintomático que os textos de Marion sempre terminem com algumas observações de cunho teológico. Transgredindo as fronteiras, não é raro encontrar momentos nos textos de Marion nos quais observações mais teológicas, mostrando como a abordagem fenomenológica não se limita ao campo da pura possibilidade, mas já indica alguma efetividade. Isso ocorre, por exemplo, em O fenômeno erótico. A pergunta que move Marion nessa obra é a busca de uma certeza. Já não mais se trata da certeza da subjetividade, mas outra: sou amado? Após páginas e páginas de descrições fenomenológicas muito bem construídas, o autor chega à seguinte conclusão: "Ao final, descubro não somente que um outro me ama antes de eu amá-lo, assim que este outro interpreta o amante muito antes de mim, mas especialmente este primeiro amante que, desde sempre, é nomeado Deus” (PE, p. 341). É plausível a suspeita de que esta conclusão não é algo a que se chega, mas é um princípio em operação desde o início da obra, inclusive determinando a pergunta central. Como se pode notar, a fenomenologia deixa de ser simples guardiã da possibilidade de fenômenos saturados para se tornar efetiva em conceitos estritamente teológicos. Em outros termos, não é viável permanecer apenas na vacuidade do discurso da possibilidade. Ao menos em Marion, o passo rumo à efetividade é dado. Isso evidencia a dificuldade de se permanecer meramente na possibilidade, sem a efetivação dessa possibilidade. Onde se chega com isso? Para Marion, a fim de garantir a especificidade da religião (assim como em Tillich), há de complementar a fenomenologia com a teologia. Mas, há uma diferença importante. Enquanto Tillich privilegia a teologia filosófica, Marion não hesita em atribuir à teologia conotações claramente cristãs.

\section{Conclusão}

Como se pode observar, Tillich e Marion partem de problemas similares: como a filosofia da religião pode abordar seu objeto sem destitui-lo de suas características mais próprias e, ao mesmo, tempo sem que o discurso filosófico se desfigure? No caso de Tillich, busca-se uma síntese. Uma vez que não pode haver 
dois absolutos, o absoluto da religião e da filosofia (cultura), busca-se justamente o elemento de síntese entre ambos. Essa síntese é encontrada na articulação entre as formas finitas e o incondicinal.

Já, em Marion, a revelação se mostra como absoluto que contrasta a fenomenologia nos limites do ego e do horizonte. Se em Tillich, a síntese se mostrava como caminho, Marion aposta na distinção entre fenomenologia e teologia. A afirmação do fenômeno saturado (e da revelação) segue no sentido de mostrar a especificidade da revelação. Ela é totalmente outra em relação aos demais fenômenos. Esse ponto fica evidente, quando Marion afirma que a revelação é absoluta, no sentido de que não há nenhuma analogia possível entre ela e os demais fenômenos. Nesse caso, é possível identificar um problema argumentativo em Marion. Tillich não tem esse problema justamente por reconhecer a síntese entre filosofia e religião. Como algo que se coloca como absoluto pode reconhecer um outro que não a si próprio? Em outros termos, se a revelação é tida como absoluta, como pode haver algo que não é abarcada por ela? Afinal, em sentido estrito, absoluto não pode ser relativo a nenhum outro. Ele deve abarcar tudo, não reconhecendo nenhum outro diferente de si. Por mais que tente superar a filosofia do sujeito, em momentos como esses, Marion revela sua dependência desse paradigma. Isso porque a revelação é absoluta em relação à delimitação do horizonte por parte de um ego. Sendo assim, no limite, a subjetividade ainda se constitui como ponto de referência. Mesmo que seja para negá-la, ela ainda é lugar a partir de onde as diferenciações podem ser feitas. Um fenômeno somente pode ser saturado em relação à subjetividade. Ainda é a perspectiva da subjetividade que é tomada como referência. Essa suspeita é fortalecida quando se atenta que as descrições que Marion oferece dos fenômenos saturados partem de uma inversão de Kant e Husserl. E, inverter não significa necessariamente subverter. Pode-se repetir a velha estrutura numa nova roupagem. 
Em todo o caso, cabe pontuar que Tillich e Marion partem do mesmo problema, mas buscam soluções por caminhos distintos. Tillich segue pela via da síntese. Marion, por sua vez, busca destacar o caráter peculiar da religião (como revelação). No entanto, ambos acabam por chegar a lugares muito próximos. Tanto em um caso, como em outro, a filosofia da religião parece condenada a recorrer à teologia caso queira tratar o seu tema de maneira adequada. Em Tillich, o incondicional assume realidade e, uma vez que não é apenas uma função do espírito, mas aquilo que permeia todas as demais funções, a filosofia deve ser religiosa e, no limite, tratar de Deus. No caso de Marion, a teologia se mostra ainda mais determinante. Ela traz certos temas para a abordagem filosófica. Mais do que isso. Para que a fenomenologia não fique num discurso mais abstrato, recorre à teologia para mostrar como possibilidades podem se efetivar. A resposta sobre o que fazer com os fenômenos saturados parece que encontra sua resposta na efetivação operada pela teologia. De todo modo, cabe destacar que enquanto Tillich recorre (ao menos nesse momento de sua trajetória) à noção de uma teologia filosófica, em Marion teologia tem sentido claramente mais restritivo. É, antes de mais anda, teologia cristã.

Essas considerações sobre esses dois pensadores servem mais para trazer alguns problemas do que propriamente soluções. Em primeiro lugar, afirmar que o tema da filosofia da religião é a religião já não deve ter perdido seu caráter de obviedade. Em segundo lugar, o reconhecimento do caráter específico da religião rompe com o tratamento conferido à ela por grande parte dos pensadores da modernidade. Ela não se limita a ser uma esfera social ou função do espírito humano entre outras. A religião advoga para si um posicionamento distinto. Também a destituição da religião de seu caráter próprio para submetê-la ao princípio de razão suficiente, mostra-se reducionista e não faz justiça ao fenômeno. Nesse sentido, a fenomenologia dá importante passo. Mas, a religião ainda não é propriamente tratada por ser reduzida ao sujeito, exigindo assim alargamento teórico da fenomenologia. Mas, ainda parece que o impasse se coloca. É possível que a filosofia da religião trate de seu tema, evitando reducionismos, sem desaguar na teologia? Ou será parte da sina da filosofia da religião, quando quer considerar o 
seu objeto de modo apropriado, ser antessala para o discurso teológico? É possível que filosofia da religião trate de seu tema adequadamente sem se anular, tornandose teologia? Se a questão da possibilidade de tratamento adequado da religião parece mais bem encaminhada, o tema da relação e da autonomia da filosofia da religião em relação à teologia ainda parece se impor como questão aberta.

\section{REFERÊNCIAS}

GRECO, Carlo. A experiência religiosa. Essência, valor, verdade. Tradução: Alda da Anunciação Machado. São Paulo: Loyola, 2009.

HEIDEGGER, M. Marcas no caminho. Trad. Enio Paulo Giachini e Ernildo Stein. Petrópolis: Vozes, 2008

HIGUET, E. Os métodos da filosofia da religião de Paul Tillich. In: Correlatio, Vol. 10, no.20, 2011, p. 27-41. Disponível em: https://www.metodista.br/revistas/revistasims/index.php/COR/article/viewArticle/3004 Visitado em 27/04/2014. Acesso em: 27/04/2014.

HORNER, Robyn. Jean-Luc Marion. A Theo-logical Introduction. Aldershot: Ashgate, 2005 .

HUSSERL, E. Gesammelte Werke. Husserliana. Volume XVIII: Edmund Husserl, Logische Untersuchungen. Erster Band: Prolegomena zur reinen Logik. Text der 1. Und der 2. Auflage. Dordrecht: Kluwer, 1975.

HUSSERL, E. Idéias para uma fenomenologia pura e para uma filosofia fenomenológica. Trad. Márcio Suzuki. Aparecida: Idéias \& Letras, 2006.

JANICAUD, Dominique. Phenomenology and the "Theological Turn". New York: Fordham University Press, 2000.

MARION, Jean-Luc. In Excess: studies of Saturated Phenomena. Trad. Robyn Horner e Vicent Verraud. New York: Fordham University Press, 2002a.

MARION, Jean-Luc. God without Being. Trad. Thomas A. Carlson. Chicago: Chicago University Press, 1991.

MARION, Jean-Luc. O visível e o revelado. Trad. Joaquim Pereira. São Paulo: Loyola, 2010.

MARION, Jean-Luc. Prolegomena to Charity. Trad. Stephen Lewis. New York: Fordham University Press, 2002b. 
MARION, Jean-Luc. Reduction and Giveness: Investigations of Husserl, Heidegger and Phenomenology. Trad. Thomas A. Carlson. Evanston, IL: Northwestern University Press, 1998.

SMITH, Wilfred. O sentido e o fim da religião. Trad. Geraldo Korndörfer. São Leopoldo: Sinodal, 2006.

TILLICH, P. Über die Idee einer Theologie der Kultur. In: TILLICH, P. Main

Works/Hauptwerke. Band2. Berlin/New York: de Gruyter - Evangelisches Verlagswerk, 1990,

TILLICH, P. Main Works /Hauptwerke. Band 4. Berlin/New York: de Gruyter Evangelisches Verlagswerk, 1987. 